JURNAL

KARAKTER NORMATIF ISI NASKAH AKADEMIK UNDANG-UNDANG

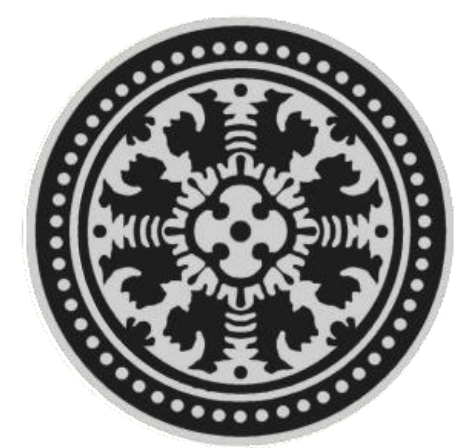

NI PUTU NITI SUARI GIRI

NIM. 1090561031

PROGRAM MAGISTER

PROGRAM STUDI MAGISTER (S2) ILMU HUKUM

PROGRAM PASCASARJANA

UNIVERSITAS UDAYANA

2013 


\title{
KARAKTER NORMATIF ISI NASKAH AKADEMIK UNDANG-UNDANG
}

Oleh :

\section{NI PUTU NITI SUARI GIRI}

\begin{abstract}
ABSTRAK
Naskah akademik harus disertakan dalam mengajukan RUU, baik oleh DPR, Presiden maupun DPD. Hal ini sesuai dengan pengaturan Pasal 43 ayat (3) Undang-Undang Nomor 12 Tahun 2011 Tentang Pembentukan Peraturan Perundang-Undangan Namun fungsi dari keharusan disertakannya naskah akademik dalam pengajuan RUU masih belum dipahami dengan baik, sehingga naskah akademik masih disepelekan dan diabaikan di dalam pengajuan RUU. Bertitik tolak dari permasalahan tersebut, maka permasalahan yang muncul yaitu Apakah karakter normatif isi naskah akademik menurut hukum dan doktrin ilmu hukum.

Tujuan dari penelitian ini, yaitu untuk memahami karakter normatif isi naskah akademik menurut hukum dan doktrin ilmu hukum. Penelitian yang digunakan adalah penelitian yuridis normatif. Sumber bahan hukum yang digunakan terdiri dari peraturan perundang-undangan, literatur-literatur, hasil penelitian, makalah-makalah dalam seminar, jurnal, artikel-artikel, dan bahanbahan bacaan yang berkaitan dengan permasalah yang dalam penelitian ini, serta kamus dan ensiklopedia hukum.

Penggunaan kata 'harus' dalam suatu undang-undang, bahwa kata 'harus' digunakan untuk pemenuhan suatu kondisi atau persyaratan tertentu. Apabila keharusan yang diatur tidak terpenuhi, maka yang bersangkutan tidak mendapatkan hal yang seharusnya akan didapat apabila persyaratannya terpenuhi. Jadi pengaturan pada Pasal 43 ayat (3) tersebut valid. Sifat dari
\end{abstract}


pengaturan mengenai keharusan menyertakan naskah akademik dalam mengajukan RUU adalah bersifat imperatif. Kata 'harus' tersebut mengikat DPR, Presiden dan DPD untuk menyertakan naskah akademik. Apabila naskah akademik ini tidak disertakan, maka konsekuensinya RUU yang diajukan tidak dapat diproses ke tahap selanjutnya.

\section{Kata kunci : naskah akademik, karakter normatif, valid}

\section{ABSTRACT}

The Article 43 (3) Act Number 12, 2011 concerning Regulations Making stipulated that the act draft from DPR, President, or DPD must be accompanied the academic text. However the function was from the obligation enclosed by the submitting the academic text still not well understood, so as the academic text was still being considered unimportant and ignored in the submitting act draft. Starting from these problems, then the problem that emerged that is what is the normative character of the contents of the academic text according to the law and the doctrine of legal knowledge.

The purpose is to understand the character of the normative content of the academic text according to the law and the doctrine of legal knowledge. The research that used was the juridical normative research. The legal source took form the regulations, literatures, results of the researches, papers in the seminar, the journals, articles, and reading materials that were linked with the problem that was studied in this research, the dictionaries and the legal encyclopedias.

The use of the word 'shall' in the regulations, that words is used for the fulfillment of a condition or specific requirements. If the obligation that was arranged this was not fulfilled, that was relevant did not receive something or the matter that necessarily will be got if the condition or this condition was fulfilled. So the regulation to the Article 43 (3) was valid. The characteristics from the regulation 
concerning the obligation enclosed the academic text in putting forward the act draft was to be imperative. The word 'shall' bind the DPR, President and DPD to submitting the academic text. If the academic text was not submitted, then the consequences that the act draft could not be processed to the further stage.

\section{Key words : academic texts, normative character,valid}

\section{PENDAHULUAN}

\subsection{Latar Belakang}

Pada Pasal 43 ayat (3) UU No. 12/11 Tentang Pembentukan Peraturan Perundang-Undangan yang merupakan UU pengganti dari UU No. 10/04, diatur bahwa RUU yang berasal dari DPR, Presiden, atau DPD harus disertai dengan naskah akademik. Kata 'harus' dalam perumusan tersebut menuntut baik DPR, Presiden ataupun DPD dalam mengajukan rancangan undang-undang untuk menyertakan naskah akademik. Pengecualian tidak perlu menyertakan naskah akademik terhadap pengajuan RUU APBN, RUU Perpu, atau RUU Pencabutan UU atau Pencabutan Perpu diatur pada Pasal 43 ayat (4) UU No. 12/11. Hal ini dapat dilihat dari sifat norma yang akan diatur pada RUU tersebut. Sifat norma yang akan diatur dalam RUU APBN, RUU Perpu, atau RUU Pencabutan UU atau Pencabutan
Perpu ini, bersifat khusus dan tidak mengatur hal-hal yang langsung mengatur permasalahan yang terjadi di masyarakat. Berdasarkan atas Pasal 43 ayat (5) UU No. 12/11, pengajuan RUU APBN, RUU Perpu, atau RUU Pencabutan UU atau Pencabutan Perpu disertai dengan keterangan yang memuat pokok pikiran dan materi muatan yang diatur.

Naskah akademik, berdasarkan pengaturan Pasal 1 angka 11 UU No. 12/11 merupakan naskah dari hasil penelitian hukum dan hasil penelitian lainnya terhadap suatu permasalahan yang dapat dipertanggungjawabkan secara ilmiah mengenai pengaturan permasalahan tersebut dalam suatu RUU, Ranperda Provinsi atau Ranperda Kabupaten/Kota sebagai solusi terhadap permasalahan dan kebutuhan hukum di masyarakat. Sebaliknya, menurut Harry Alexander, naskah akademik merupakan naskah awal yang berisi ide-ide 
pengaturan dan materi muatan suatu peraturan dalam bidang tertentu. Bentuk dan isi naskah akademik berisi gagasan pengaturan suatu materi hukum dalam bidang tertentu yang sudah dikaji dari berbagai aspek ilmu yang dilengkapi dengan referensi yang memuat; urgensi, konsepsi, landasan, dasar hukum, prinsipprinsip yang digunakan serta pemikiran mengenai norma-norma yang telah ditransformasikan ke dalam bentuk pasalpasal dengan mengajukan beberapa alternatif yang dapat dijadikan bahan pertimbangan, yang diuraikan secara sistematis dan dapat dipertanggungjawabkan secara ilmu hukum. ${ }^{1}$

Pada tahap penyusunan, naskah akademik, selain berisi dasar-dasar, alasan-alasan dan pertimbanganpertimbangan yang tidak semata-mata politik, akan tetapi juga berisi dasar pertimbangan yuridis, sosiologis dan filosofis dari RUU yang akan diajukan. ${ }^{2}$ Dengan berlandaskan atas tiga hal tersebut, naskah akademik yang dibuat tidak saja bertumpu pada keilmuan (berdasarkan pertimbangan dari segi filosofis dan yuridis) tetapi juga ditunjang dengan kenyataan sosial (berdasarkan

\footnotetext{
${ }^{1}$ Sirajuddin, Fatkhurohman dan Zulkarnain, 2008, Legislative Drafting, Yappika, Jakarta, h. 123-124.

2 Bagir Manan, 1992, Dasar-Dasar PerundangUndangan Indonesia, Ind-Hill Co, Jakarta, h. 1819.
}

pertimbangan dari segi sosiologis). Tumpuan keilmuan dibuat berdasarkan kaidah-kaidah teori dan doktrin sedangkan tumpuan kenyataan didasarkan pada kebutuhan nyata yang diinginkan masyarakat. $^{3}$ Disusunnya naskah akademik ini oleh para akademisi atau ahli-ahli dari perguruan tinggi, maka diharapkan naskah akademik dapat bermanfaat dalam penyusunan rancangan undang-undang. Namun fungsi dari keharusan disertakannya naskah akademik dalam pengajuan RUU masih belum dipahami dengan baik, sehingga naskah akademik masih disepelekan dan diabaikan di dalam pengajuan RUU.

\subsection{Rumusan Masalah}

Berdasarkan uraian pada latar belakang, terdapat permasalahan yang berkaitan dengan naskah akademik, yaitu Apakah karakter normatif isi naskah akademik menurut hukum dan doktrin ilmu hukum?

\subsection{Tujuan Penelitian}

Tujuan dari penelitian ini, yaitu secara umum untuk memahami hal-hal yang berkaitan dengan naskah akademik dalam penyusunan RUU dan untuk memahami karakter normatif isi naskah

\footnotetext{
${ }^{3}$ Sirajuddin, Fatkhurohman dan Zulkarnain, op.cit. h. 125 .
} 
akademik menurut hukum dan doktrin ilmu hukum.

\section{METODE PENELITIAN}

Penelitian yang digunakan di dalam penulisan penelitian ini yaitu penelitian yuridis normatif. Penelitian yuridis normatif ini mengumpulkan bahan dengan cara studi kepustakaan, yaitu dengan memperoleh data-data yang berkaitan dengan permasalahan yang diangkat melalui penelitian kepustakaan (library research).

Sumber bahan hukum yang digunakan berupa : bahan hukum primer yaitu peraturan perundang-undangan baik yang berkaitan dengan naskah akademik maupun yang mengatur mengenai naskah akademik; bahan hukum sekunder, yang terdiri atas literatur-literatur, hasil penelitian, makalah-makalah dalam seminar, jurnal, artikel-artikel, dan bahanbahan bacaan yang berkaitan dengan permasalahan yang diteliti; dan bahan hukum tersier, berupa kamus dan ensiklopedia hukum.

\section{III.PEMBAHASAN}

Naskah akademik suatu RUU merupakan suatu naskah hasil dari penelitian hukum terhadap suatu permasalahan yang dapat dipertanggungjawabkan secara ilmiah berkaitan dengan pengaturan masalah tertentu dalam suatu RUU yang akan diajukan. Dapat dikatakan bahwa naskah akademik merupakan awal mula untuk membentuk suatu RUU, karena sebuah RUU berasal dari naskah akademik, sepatutnya naskah akademik disusun berdasarkan penyusunan peraturan perundang-undangan yang baik pula, sehingga menghasilkan naskah akademik yang baik, yang nantinya setelah RUU yang disertai naskah akademik tersebut disetujui akan menghasilkan sebuah undang-undang yang baik, yang dapat menciptakan keadilan, kepatutan dan kesejahteraan bagi masyarakat.

Untuk menciptakan undangundang yang baik, sudah tentu RUU yang akan diajukan menjadi undang-undang juga harus disusun secara baik terlebih dahulu. Oleh karena berdasarkan pengaturan dari UU No. 12/11 pada Pasal 43 ayat (3) mengatur mengenai keharusan menyertakan naskah akademik bagi para pembentuk undang-undang di dalam mengajukan undang-undang, maka naskah akademik pun perlu dibuat dengan baik. Untuk menghasilkan naskah akademik yang baik perlulah menyusun naskah akademik tersebut sesuai dengan kaidahkaidah yang baik, guna menghasilkan hukum yang baik. 
Dapat disimpulkan bahwa akhirnya pemerintah mengeluarkan UU No. 12/11 ini dan mengganti UU No. 10/04, yang di dalamnya terdapat pengaturan yang tegas dan jelas mengenai penyertaan naskah akademik dalam mengajukan RUU, terdapat beberapa alasan, yaitu : ${ }^{4}$

1. Karena keberadaan naskah akademik di dalam penyusunan suatu RUU masih belum mempunyai kekuatan mengikat dan tegas, yang dikarenakan oleh naskah akademik dalam penyusunan suatu rancangan undang-undang tidak merupakan suatu keharusan bagi lembagalembaga pemerintah yang menjadi pemrakarsa penyusun RUU, demikian pula di lingkungan DPR dan DPD.

2. Karena suatu naskah akademik masih disusun berdasarkan kebiasaan-kebiasaan yang berlaku, yang dikarenakan belum adanya pedoman yang baku, yang menunjukan bahwa naskah akademik dianggap sebagai bukan suatu produk hukum.

3. Karena secara definisi ditetapkan bahwa naskah akademik merupakan suatu naskah yang

\footnotetext{
${ }^{4}$ Maria Farida Indrati S., 2011, Ilmu PerundangUndangan : Proses Dan Teknik Pembentukannya, Kanisius, Jogjakarta, h. 248-249.
}

dapat dipertanggungjawabkan secara ilmiah mengenai konsepsi yang berisi latar belakang, tujuan penyusunan, sasaran yang ingin diwujudkan dan lingkup, jangkauan, objek atau arah pengaturan RUU, seharusnya naskah akademik disusun sebelum RUU terbentuk, namun pada kenyataannya, kebanyakan naskah akademik disusun setelah rancangan undang-undangnya dirumuskan.

4. Untuk mengamati apakah pembentukan suatu undang-undang telah sesuai dengan yang direncanakan dan telah dirumuskan dalam suatu naskah akademik, diperlukan suatu risalah pembahasan yang dilakukan selama proses pembentukan undang-undang tersebut berlangsung. Pembuatan risalah yang lengkap terhadap seluruh pembahasan RUU, dapat digunakan sebagai bahan evaluasi terhadap kesesuaian naskah akademik dan undang-undang yang dibentuk, serta dapat mengetahui alasan-alasan yang mendasari setiap perumusan dalam undangundang tersebut.

Demi menunjang tercapainya suatu penyusunan undang-undang yang baik, 
serta memenuhi keinginan akan adanya harmonisasi dalam bidang perundangundangan, maka pembahasan dan kajian mengenai fungsi dan pentingnya naskah akademik bagi penyusunan rancangan undang-undang menjadi sesuatu hal yang penting.

Kata 'harus' pada Pasal 43 ayat (3), menyatakan pengertian spesifik bahwa DPR, Presiden dan DPD harus menyertakan naskah akademik dalam mengajukan RUU. Keharusan menyatakan pengertian spesifik bahwa perilaku manusia ditentukan oleh norma hukum. Tindakan yang diharuskan oleh pengaturan tersebut adalah dituntut, meskipun tidak ada yang menghendakinya. ${ }^{5}$ Ini menunjukan, pengaturan dalam Pasal 43 ayat (3) yang mengatur mengenai 'keharusan' dalam konteks ini, merupakan suatu pernyataan kehendak yang berasal dari undang-undang dalam bentuk imperatif, bahwa subjek yang diatur harus melakukan tindakan atau cara yang telah diatur dalam undang-undang tersebut.

Berdasarkan Lampiran II UU No. $12 / 11$, mengenai makna penggunaan kata 'harus' dalam suatu undang-undang, bahwa kata 'harus' digunakan untuk pemenuhan suatu kondisi atau persyaratan

\footnotetext{
${ }^{5}$ Meuwissen, 2008, Meuwissen Tentang Pengembangan Hukum, Ilmu Hukum, Teori Hukum, Dan Filsafat Hukum, Cet. 2, diterjemahkan oleh B. Arief Sidharta, Refika Aditama, Bandung, h. 42-44.
}

tertentu. Apabila keharusan yang diatur tersebut tidak terpenuhi, yang bersangkutan tidak memperoleh sesuatu atau hal yang seharusnya akan didapat apabila kondisi atau persyaratan tersebut terpenuhi. Jadi pengaturan pada Pasal 43 ayat (3) tersebut valid. Sifat dari pengaturan mengenai keharusan menyertakan naskah akademik dalam mengajukan RUU adalah bersifat imperatif. Kata 'harus' tersebut mengikat DPR, Presiden dan DPD untuk menyertakan naskah akademik. Apabila naskah akademik ini tidak disertakan, maka konsekuensinya RUU yang diajukan tidak dapat diproses ke tahap selanjutnya.

Validitas memiliki makna sebagai eksistensi spesifik dari norma. Suatu norma yang valid, artinya bahwa pengaturannya diterima atau diakui keberadaannya atau dapat dikatakan juga bahwa aturan tersebut memiliki kekuatan mengikat bagi mereka yang diatur perbuatannya oleh undang-undang tersebut. $^{6}$ Validitas hukum memiliki pengertian bahwa undang-undang tersebut mengikat, bahwa subjek yang diatur dalam undang-undang tersebut harus berbuat sesuai dengan apa yang diharuskan oleh undang-undang tersebut, bahwa subjek

\footnotetext{
${ }^{6}$ Hans Kelsen, 2007, General Theory of Law and State (Teori Hukum Dan Negara : Dasar-Dasar Ilmu Hukum Normatif Sebagai Ilmu Hukum Deskriptif-Empirik), diterjemahkan oleh H. Somardi, Bee Media Indonesia, Jakarta. h.36.
} 
tersebut harus mematuhi dan menerapkannya. Validitas merupakan kualitas dari hukum. Hukum sebagai norma yang valid menemukan ungkapannya di dalam pernyataan bahwa orang harus berbuat atau bertindak berdasarkan suatu cara tertentu. ${ }^{7}$

\section{PENUTUP}

\subsection{Simpulan}

Berdasarkan

pemaparan

sebelumnya, dapat ditarik kesimpulan bahwa karakter normatif dari naskah akademik adalah imperatif. Hal ini terlihat dari pengaturan dalam Pasal 43 ayat (3) UU No. 12/11 Tentang Pembentukan Peraturan Perundang-undangan, yaitu dengan adanya kata "harus" untuk menyertakan naskah akademik, dalam mengajukan RUU.

\subsection{Saran}

Sebaiknya di dalam proses penyusunan undang-undang, para pembentuk undang-undang harus benarbenar memperhatikan aturan-aturan yang berlaku, harus mentaati dan melaksanakan secara rinci hal-hal yang diatur berkaitan dengan proses pembentukan undangundang, sehingga tidak terjadi kesalahan ataupun kelalaian dalam pembentukan undang-undang.

\footnotetext{
${ }^{7}$ Ibid. h. 48.
}

\section{DAFTAR BACAAN}

\section{Literatur}

Alexander, Harry, 2004, Panduan Perancangan Peraturan daerah Di Indonesia, Solusindo XSYS, Jakarta.

Algra, N. E., dan K. Van Duyvendijk, 1983, Mula Hukum : Beberapa Bab Mengenai Hukum Dan Ilmu Untuk Pendidikan Hukum Dalam Pengantar Ilmu Hukum, diterjemahkan oleh J.C.T. Simorangkir, Binacipta.

Amiruddin dan H. Zainal Asikin, 2008, Pengantar Metode Penelitian Hukum, cet. IV, Raja Grafindo Persada, Jakarta.

Asshiddiqie, Jimly, 2010, Perihal Undang-Undang, PT. Konstitusi Press, Jakarta.

Atmadja, I Dewa Gede, 2013, Filsafat Hukum : Dimensi Tematis Dan Historis, Setara Press, Malang.

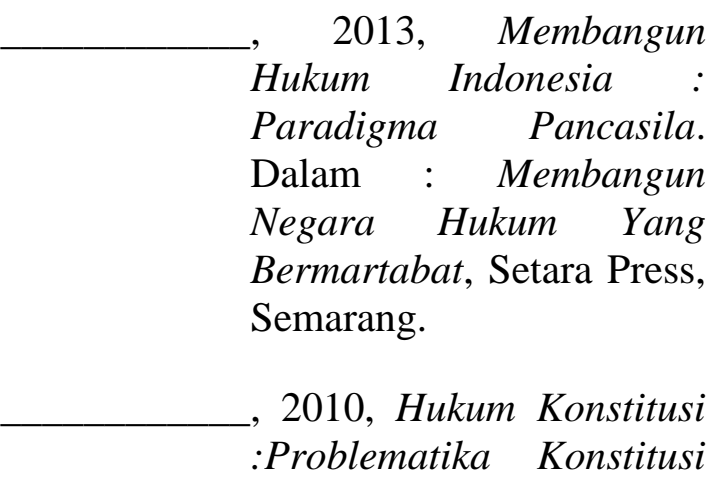


Indonesia Sesudah

Perubahan UUD 1945,

Setara Press, Malang.

Attamimi, A. Hamid S., 1992, Teori

Perundang-undangan

Indonesia : Suatu Sisi Ilmu

Pengetahuan Perundang-

Undangan Indonesia Yang

Menjelaskan Dan

Menjernihkan

Pemahaman, Pidato

Pengukuhan Jabatan Guru

Besar Tetap pada Fakultas

Hukum Universitas

Indonesia di Jakarta pada

tanggal 25 April 1992.

Bako, Ronny Sautma Hotma, 1999,

Pengantar Pembentuk

Undang-Undang Republik

Indonesia, Citra Aditya

Bakti, Bandung.

Halim, Hamzah dan Kemal Redindo Syahrul Putera, 2009, Cara Praktis Menyusun Dan Merancang Peraturan Daerah (Suatu Kajian Teoritis dan Praktis Disertai Manual) : Konsepsi Teoritis Menuju Artikulasi Empiris, Kencana Perdana Media Group, Jakarta.

Hamidi, Jazim et. al., 2008, Panduan Praktis Pembentukan Peraturan Daerah Partisipatif, Prestasi Pustaka, Jakarta.

Handoyo, B. Hestu Cipto, 2008, PrinsipPrinsip Legal Drafting Dan Desain Naskah Akademik, Cet. 1, Penerbit Universitas Atma Jaya, Yogyakarta.

Ibrahim Johnny, 2012, Teori Dan Metode Penelitian

Hukum
Normatif, Bayumedia Publishing, Malang.

Indrati S., Maria Farida, 2012, Ilmu Perundang-Undangan : Jenis, Fungsi, Dan Materi Muatan, cet. 13, Kanisius, Jogjakarta.

, 2011, Ilmu PerundangUndangan : Proses Dan Teknik Pembentukannya, Kanisius, Jogjakarta.

Islamy, M. Irfan, 1988, Prinsip-Prinsip Perumusan Kebijaksanaan Negara, Bina Aksara, Jakarta.

Kelsen, Hans, 2007, General Theory of Law and State (Teori Hukum Dan Negara : Dasar-Dasar Ilmu Hukum Normatif Sebagai Ilmu Hukum DeskriptifEmpirik), diterjemahkan oleh H. Somardi, Bee Media Indonesia, Jakarta.

Lubis, M. Solly, 1977, Landasan Dan Teknik PerundanngUndangan, Alumni, Bandung.

Mahfud MD., Moh., 2010, Membangun Politik Hukum Menegakkan Konstitusi, Cet. 1, PT. Raja Grafindo Persada, Jakarta.

2011, Politik Hukum Di Indonesia, Cet. 4, PT. Raja Grafindo Persada, Jakarta.

Manan, Bagir, 1992, Dasar-Dasar Perundang-Undangan Indonesia, Ind-Hill Co, Jakarta. 
Marzuki, Peter Mahmud, 2011, Penelitian

Hukum, Kencana Prenada

Media Group, Jakarta.

Meuwissen, 2008, Meuwissen Tentang

Pengembangan Hukum,

Ilmu Hukum, Teori

Hukum, Dan Filsafat

Hukum, Cet. 2,

diterjemahkan oleh B.

Arief Sidharta, Refika

Aditama, Bandung.

Parsons, Wayne, 2006, Public Policy : Pengantar Teori Dan Praktik Analisis Kebijakan, diterjemahkan oleh Tri Wibowo Budi Santoso, Kencana Prenada Media Group, Jakarta.

Ranggawidjaja, Rosjidi, 1998, Pengantar Ilmu PerundangUndangan Indonesia, Mandar Maju, Bandung.

Rapar, J.H., 2001, Filsafat Politik, Raja Grafindo Persada, Jakarta.

Sirajuddin, Fatkhurohman dan Zulkarnain, 2008, Legislative Drafting : Pelembagaan Metode Partisipatif Dalam Pembentukan Peraturan Perundang-undangan, Cet. 3, In-TRANS Publishing Malang, Malang.

Vlies, I.c Van Der, 2005, Buku Pegangan Perancangan Peraturan Perundang-Undangan, diterjemahkan oleh Linus Doludjawa, Direktoral Jenderal Peraturan Perundang-Undangan Departemen Hukum Dan
Hak Asasi Manusia Republik Indonesia, Jakarta.

Yuliandri, 2009, Asas-Asas Pembentukan Peraturan PerundangUndangan Yang Baik : Gagasan Pembentukan Undang-Undang

Berkelanjutan, Raja Grafindo Persada, Jakarta.

\section{Peraturan Perundang-Undangan}

Undang-Undang Nomor 12 tahun 2011 Tentang Pembentukan Peraturan PerundangUndangan, Lembaran Negara Republik Indonesia Tahun 2011 Nomor 82, Tambahan Lembaran Negara Republik Indonesia Nomor 5234. 


\section{BIODATA PENULIS}

Nama $\quad$ : Ni Putu Niti Suari Giri, S.H.

Alamat : Jalan Gunung Agung, gang Bumi Ayu G, nomor 4.

No. telpon : 082146140487

Email : shirayuki_mate89@yahoo.com 